\title{
Learning from student expectations of higher education: a study in a public university in Malaysia
}

\author{
Premalatha Karupiah, Universiti Sains Malaysia \\ Intan Hashimah Mohd Hashim, Universiti Sains Malaysia \\ Norzarina Mohd-Zaharim, Universiti Sains Malaysia
}

\begin{abstract}
This study looks at the expectations of undergraduate students in one public university in Malaysia with regard to the introduction of the Accelerated Program for Excellence (APEX). The university has undergone major transformations, which consequently influence the expectations of students. This paper uses two sets of data: data collected through six focus group interviews and data from responses to a series of open-ended questions. These open-ended questions were part of a bigger survey consisting of 275 undergraduates, but only responses related to the open-ended section were included in this analysis. Student expectations can be categorized into expectations related to educational qualification and their projected future; teaching, learning and assessment; and information technology and communication. We suggest that universities need to take into consideration students' realistic expectations and manage unrealistic expectations. We also argue that universities need to be cautious in viewing students as consumers in order to function as institutions that generate and disseminate knowledge to students.
\end{abstract}

Keywords: APEX university; Malaysia; Accelerated Program for Excellence; student expectations; service gap; service quality

\section{Introduction}

Higher education institutions around the world are going through major changes both in terms of their role and consequently the perceptions of their stakeholders. Higher education institutions which used to be centres of knowledge are now becoming similar to business organizations which deliver services to their customers (Darlaston-Jones et al., 2003). The view that higher education is a commodity is not new. Historically, royalties and land owners have employed tutors to teach their children (Kaye et al., 2006). The only difference at present is that the view that higher education is a commodity that can be bought is coupled with a consumerist culture where consumers often expect tangible benefits from the purchase of a commodity (Kaye et al., 2006). The present consumerist culture has forced higher education institutions to work towards meeting customer demands and expectations like any other business organizations. Using business models to evaluate higher education institutions is problematic because in reality these institutions play a much more important and different role than merely delivering services to fulfil customer expectations (Kaye et al., 2006). These institutions are expected to function as a place where knowledge is disseminated and new knowledge and ideas are constantly discovered (Kaye et al., 2006).

P. Karupiah
I. H. M. Hashim
N. Mohd-Zaharim


The Malaysian education system has undergone transformation in recent years. This can be reflected in the rapid development of private higher education institutions. Prior to 1996, the government was solely responsible for university education (which includes undergraduate and postgraduate degrees) even though private higher education institutions provided courses which offered certificates and diplomas. It was only after 1996 that private universities were established and provided undergraduate and graduate degrees. The number of both public and private universities has grown in recent years. This directly and indirectly increases the competition faced by these institutions (see the following section for a more detailed discussion on Malaysian higher education). Private universities face immense competition to enrol students. Public universities may not face such high competition for undergraduates because of their reputation as public universities, a highly subsidised fee structure, and availability of government financial assistance. The government subsidises 85 to 95 per cent of fees in public higher learning institutions (Bernama, 2012, as cited by Lee, 2014). Malaysia's spending of public expenditure per student is considered one of the highest in the world, and this includes loans and scholarships that are given to students by various government agencies (Lee, 2014). More than half of these financial assistances are given to students in public higher learning institutions ${ }^{1}$. Private and public higher learning institutions play both a complimentary and competitive roles in providing higher education to their consumers, i.e. students (Wan, 2007).

As the main consumers of higher education, students often have various expectations towards higher education. Their expectations are valuable and are a great source of information (Sander et al., 2000). A consumerist view of higher education is often associated with high expectations of students (Jones, 2010). Studies have shown that interactive quality (i.e. academic instruction, guidance), physical quality (i.e. teaching and learning facilities, equipment, and accommodation) and corporative quality (i.e. recognition, reputation) are important to students in higher education (Pereda et al., 2007). However, applying the consumer analogy to students is often problematic (Bay \& Daniel, 2001). The role of a consumer and the nature of consumption in education are very different from other products or services. This is because the success of higher education depends not only on how the service is delivered, but the effort, participation and contribution of the customer, i.e. the student (Bay \& Daniel, 2001; Jones 2010; Kaye et al., 2006). Students do not come to university merely to consume, but as collaborative partners who bring knowledge and skills to the university (Bay \& Daniel, 2001). Another unique quality of higher education institutions is that they provide services over a long period of time and the quality of the services delivered may not be experienced immediately but throughout a person's life (Urban, 2009). For example, an engineering student who takes an introductory class in management may use that knowledge he/she acquired from the management class ten years after entering work force when he/she is required to manage a group of subordinates.

Traditionally, the success of an academic institution depended on academic standards and accreditation (Abdullah, 2006). Today, the success and survival of institutions of higher learning depend on how well they deliver these services and are able to compete with other higher learning institutions. Another unique feature of higher education institutions is that although they deliver their services to students, they are also required to meet the expectations of students, parents, university leaders, community leaders and to some extent the wider society in general.

\begin{tabular}{r|r} 
P. Karupiah & 22 \\
I. H. M. Hashim & \\
N. Mohd-Zaharim &
\end{tabular}


Therefore, the act of meeting customer demands becomes multi-faceted in higher education unlike other service organizations.

The gap between customer expectation and perception of services is called the service quality gap. There are five dimensions used by customers to evaluate service quality: reliability, responsiveness, assurance, empathy and tangibles (Parasuraman \& Grewal 2000; Parasuraman et al., 1988). Urban (2009) identified eleven typical gaps at a public university, including the gap in understanding future labour demands and changes in society, and the gap between formal guidelines and the translation of these guidelines to operative procedures (Urban, 2009). The gap between student expectations and services delivered will result in disappointment and frustration on the part of the students, their parents, leaders and society. Keeping the nature of consumption in higher education in mind, there is a need to identify and discern unrealistic expectations. This is because an institution of higher learning is not only responsible for fulfilling student expectations, but to give students a meaningful education. Ultimately, it is responsible for training students based on the requirements of various academic and professional disciplines which is expected to help the survival of society in the future.

This paper is based on a study which explores the understanding, expectations and aspirations of Universiti Sains Malaysia (USM) undergraduate students towards the university after it was selected for the Accelerated Programme for Excellence (APEX) in 2008. USM is a Malaysian public university located in the state of Penang. This paper explores the expectations of USM undergraduate students towards the APEX. The introduction of the APEX is an important milestone in the higher education system in Malaysia because it is expected to push USM to become an internationally renowned higher educational institution. APEX is also expected to give more autonomy and funding to USM which may increase student expectations towards the university. This paper, therefore, identifies realistic and unrealistic expectations of the students and gives recommendations for the steps that can be taken by the university in order to manage these expectations.

\section{Changing Higher Education System in Malaysia}

The Malaysian government has been the main force in the development of higher education in Malaysia, and there have been major changes in the number of public and private higher education institutions. In 2002, there were eleven public universities (Lee, 2004) and by 2009 the number increased to twenty public universities (Fernandez, 2010). Prior to 1996, there was no private university in Malaysia. In 1996, the enactment of Private Higher Education Institutions Act made it possible for the establishment of private universities (Wan, 2007). The number of private universities increased to twelve in 2002 (Lee, 2004) and now there are twenty six private universities in Malaysia. With the rapid development in private higher education in Malaysia, the government moved from being the main provider of higher education to being responsible for maintaining the quality of education provided by educational institutions (Lee, 2004).

In 2006, four universities in Malaysia, i.e. Universiti Malaya (UM), Universiti Sains Malaysia (USM), Universiti Kebangsaan Malaysia (UKM) and Universiti Putra Malaysia (UPM), were designated as research universities to intensify research, development and commercialization

P. Karupiah
I. H. M. Hashim
N. Mohd-Zaharim


outputs at these institutions of higher learning. In August 2008, the government selected USM for the APEX in recognition of it being the university with the highest potential to become the first world class university in Malaysia (Kabilan et al., 2010).

Some of the objectives of APEX are to speed the transformation of higher education; promote top level research and teaching; encourage cooperation with other universities; re-examine existing structures, norms and business models to promote competitiveness and performance; and human capital development (Nik Husin et al., 2012). Also, the university aims to continue its objective of being a sustainability-led university, where research and activities related to various kinds of sustainability are given importance (Razak \& Mohamed, 2008). Other than environmental sustainability, USM hopes to ensure that economic, cultural and social sustainability is emphasized both by the university and the community in general. As part of the emphasis on economic, social and cultural sustainability, USM aims to concentrate on helping marginalized communities around the world. With these aims, the university was given more autonomy with regards to finance, service scheme, administration, student intake, appointment of staff, and tuition fees (Nik Husin et al., 2012).

In 2009, USM made undergraduate student selections at the university level. Prior to this, selection of undergraduate students for all public universities in Malaysia was done by a centralized processing agency, The Division of Student Admission (Fernandez, 2010). Currently, USM is the only public university that has a separate selection mechanism for undergraduate students. In order to achieve its aims, the university under the APEX will be provided with stateof-the-art facilities to attract outstanding students and scholars from across the world. In line with such high aims, the performance of this university will be benchmarked against other top universities around the world (Nik Husin et al., 2012). The vision is to ensure that USM is able to compete with other top universities, and is able to help and support marginalized communities around the world (Razak, 2009). This is expected to redefine the meaning of a world class university and is a tall order to achieve.

The changes in higher education in Malaysia have been driven by the government, influenced by major changes in the international higher education scenario. Most of the changes in Malaysia have been made by the government through a top-down approach. One element that is missing in this is the attention which needs to be given to the 'customers' of higher education. Even though using the term customer to refer to students is rather problematic, other studies have consistently shown the importance of student expectations in improving the quality of higher education (Pereda et al., 2007). This study, therefore, is very important as it focuses on student expectations and makes policy recommendations based on these expectations in order to further improve the quality of higher education in Malaysia.

\section{Data and methods}

Two sets of data were used for this paper. The first set of data was collected from six focus group interviews involving 30 undergraduates in USM after it was selected as the university for APEX. Participants in the focus group interviews ${ }^{2}$ were selected using a purposive sampling method, and were selected from six schools, i.e. Industrial Technology, Social Sciences, Educational

\begin{tabular}{r|r} 
P. Karupiah & 24 \\
I. H. M. Hashim & \\
N. Mohd-Zaharim &
\end{tabular}


Studies, Mathematical Sciences, Humanities and Biological Sciences. These schools were selected to allow the participation of students from various programmes and academic disciplines in the focus group interviews. There were about 37 per cent male and 63 per cent female participants. All the students were between 20 to 25 years old.

The second set of data was collected from a sample of 275 undergraduate students. The data were part of the larger survey where respondents were selected using a cluster sampling method. Each school was considered as one cluster. Nine schools were randomly selected from 24 schools offering full time undergraduate programs located on USM main campus in Penang Island; Engineering Campus in Nibong Tebal, Penang; and Health Campus in Kubang Krian, Kelantan. Based on the ratio of the number of schools in each campus, six, two and one school/s were selected from the main, engineering and health campus, respectively. Self-administered questionnaires were distributed in English Language classes attended by students from the selected schools. In the university, all undergraduate students are required to take three levels of English language course as a requirement for graduation. Questionnaires were distributed in these compulsory classes. The sample consisted of 202, 37 and 36 students from the main campus, engineering campus and health campus, respectively.

The original questionnaire was divided into six sections. The analysis in this paper focuses on data in the last section of the questionnaire which consisted of a series of open-ended questions related to student expectations towards and understanding of APEX. Students used either Malay or English in the focus group interviews and questionnaires. All names used are pseudonyms. When transcribing and/or translating the interviews, the researchers focused on maintaining the language style and slang used in Malaysia; therefore some parts of the conversation may not be grammatically correct.

After transcription and/or translation, the researcher went through the transcripts for familiarization, before coding was carried out. These codes were analysed to discover themes related to the research questions of the study. A theme usually captures an important element related to the research questions, and reflects some important meaning in the data that have been collected. Therefore, the researchers identified various themes in the data which represented different aspects of student expectations. Names which reflected the meaning of the theme were identified, and are presented below.

\section{Student expectations}

Student expectations from this study have been divided into three themes. Student expectations focused mostly on their projected future; teaching, learning and assessment; and ease of communication and information technology.

\section{Educational qualification and the projected future}

In all of the focus group interviews, at least one participant discussed his/her expectations related to his/her future work life. When they enrolled in their respective programmes, many students had the expectation that they would be ready for the world of work when they graduated. Many

\begin{tabular}{r|r} 
P. Karupiah & 25 \\
I. H. M. Hashim \\
N. Mohd-Zaharim
\end{tabular}


seemed rather disappointed because even though they were in their second or final year of studies, they were still unclear about what they would do when they graduated. Such views were prevalent among students from pure arts and sciences such as social sciences, humanities, and mathematics. On the contrary, students in programmes such as computer science, education, and engineering did not express such concern. Aziz, a male undergraduate student explained:

'When I came to university I felt that when I go out I will be ready to work. I am in my third year, but I am still not sure what I will do when I graduate. I see my friends all know what to do. I just wish that the university has prepared me better'.

Another student Tan expressed similar views.

'Ya [Yes], I agree with that. I think they need to teach us more skills which I can use at work. I saw my friends from the engineering school all got job offers during the career fair. For me it is not like that. I have a degree in Geography. I still don't know what to do. I think the university needs to teach us what to do when we start working'.

Another student, Nani, highlighted that assessment should be changed to include assessment of skills related to career and field of studies.

When asked if they had any training related to work while being in the university, Ahmad, explained:

'I learnt how to write a résumé and how to attend interviews. They taught us what to prepare before interviews and things like that'.

Another student, Rose explained:

'We also have a course on entrepreneurship to help us if we want to become an entrepreneur. We have also done a project for that course. It is a basic course. So, I think it is not enough...I need to know where to get money [loan], how to apply for a license if I want to start a business. I need more information on that'.

All of them agreed that they have attended some programs or training on skills related to their career, but felt that it was not enough. Many students who were in pure science or arts and humanities programmes were not sure how to relate/use what they had learnt in class to the world of work. There seemed to be a gap between their expectations on how they thought they would feel when they graduated and how they currently felt towards the end of their programme. This seemed to be mainly due to the fact that students equated university education to vocational training. Some programmes at the university are not meant to provide specific vocational training to students. In fact, the forerunners of university taught liberal arts to people who were not looking for training of any particular skill or trade. For them, education was not pursued for economic gains. This, however, may be very different in our present consumer culture, but the fact remains that even though some degree programmes do provide some form of vocational training, many programmes (e.g. in pure arts and sciences) are not designed to provide specific 
vocational training. Students enrolled in these programmes sometimes felt lost upon completion of their programmes because they were not aware of the nature of their course and were expecting to get vocational training during their programmes. Students' concerns regarding their future clearly showed that they did not perceive a university as a bastion of knowledge, but an institution which teaches appropriate skills to ensure their employability in the future.

\section{Teaching, learning and assessment}

Many students had expectations that the teaching in the university should be improved to suit their needs. Students who enrolled at the university came from very diverse backgrounds, therefore they expected the lecturers to take those differences into account in class. Anees, a student in the second year, explained

'When I first got here I felt so lost, especially the first few weeks on campus. When we were in school, it was very different. The teachers always told us what to do. I didn't listen to them sometimes, but they told us. When I came here it is all different. We have to move from one class to another, choose courses, adjust timetable, so many things to do. So, I hope lecturers in the first year, consider all this when they are teaching'.

Tan, another student, explained:

I expect the teaching process to be improved. Now that we are becoming a world class university, I think it is important to focus on this. Only then can we have world class students. We hear that there will be more research and more Master's and PhD students. That is good. At the same time the teaching process needs to be more interesting and exciting'.

Tan's view is an indication of high expectations among students regarding teaching and learning at the university. It suggests that students felt that teaching should involve a variety of methods which may include lecture, group work and other interactive methods of teaching.

Many students expected an increase in the role of technology in education. They expected to see major changes happening with the use of technology in their classroom and the optimization in the use of technology in the teaching and learning process. Michelle said:

'There are so many new technologies today, but sometimes we feel that the correct technology is not used. Sometimes lecturers use minimum technology. For example the projector is usually used to show PowerPoint slides. I think much more can be done using technology to make lessons more interesting and exciting...I watched a documentary, I was amazed with the use of equipment in some of the universities. Now that we are APEX, I think we will get all the equipment fast'.

Many participants expected some form of changes in the ways they were assessed. Nani, a female student explained: 
'Since we are an APEX university maybe we can eliminate examinations or at least change them. At the moment we are using written examinations...I just memorize and write in the exams. After that I don't remember it. It is not practical. I can't use it in a practical sense. So maybe we need to change the assessments. I think [written] exams are not the best way to assess a person...Maybe oral exams are better. If students can present that means they understand'.

Other members of the focus group disagreed that examinations needed to be eliminated, but they explained that examinations were very stressful. They felt that exams were not the best way of assessing students' knowledge and ability. Therefore, they hoped that some class tests could be reduced or changed to computerized tests or other forms of assessment such as projects or assignments. Some other members explained that in some courses, computerized tests were used and they sometimes found them difficult.

Whilst online learning and assessment has become part of higher education, it challenges educators to reconceptualise issues related to teaching, learning and assessment in a nontraditional space. Studies have found that online formative assessment together with formative feedback is able to improve students' learning experience, but educators need to address the threats to validity and reliability of online formative assessments (Gikandi et al., 2011). In the context of USM, it has moved from the traditional 'chalk and talk' method of teaching and purely exam-oriented assessments. It has also and incorporated e-learning and increased the use of technology in the teaching, learning and assessment process. However, there is a need to further improve the assessment methods in order to help the learning process and accurately assess the abilities of students. The students felt that alternative methods of assessment would be useful in making a more accurate assessment of their ability and skills.

\section{Information technology and communication}

In the focus group interviews and survey, the Internet was an important expectation of the students. Even though Internet (either wired or wireless) is available on campus, this was stated as being very important to them.

'There have been many changes. Before and after APEX, I notice a lot of changes. The library and hostels have been improved. There are many more books in the library. It does not mean there were no books earlier but now there are many more...but I wish there were more changes... for example, I hope the Internet services are improved further. Now it is good. I just hope it is faster'.

In addition, students explained that they relied heavily on electronic resources for their assignments and references. Therefore, they had very high expectations that the university would provide fast and stable network. Ani explained:

'If we have a fast and stable network, we can communicate easily with lecturers, tutors, etc. Sometimes this way will be easier to say what we want to say, it is easier to ask question [s], especially on Facebook'.

\begin{tabular}{r|} 
P. Karupiah \\
I. H. M. Hashim \\
N. Mohd-Zaharim
\end{tabular}


Students perceived that a greater use of information and communication technology would increase the interaction between the instructor and them. They felt that this helped the ease of communication, but also changes the nature of communication between them. Traditionally, in Malaysian society communication between a teacher and his/her student is mostly hierarchical and formal in nature. They felt that communication done electronically made their interaction less formal especially when communicating through social networking sites. When asked if they had their lecturers on their friends' list on Facebook, Ani explained:

'Only a few. Not all lecturers are OK with accepting my friend request. Well, maybe they don't think of me as their friend'.

The reluctance of some lecturers to use social networking sites for communication shows that some lecturers prefer to set certain boundaries in their communication with students. Information technology plays a very important role in every aspect of our lives, work, education, family and leisure. The excerpts above show how vital information technology is to the lives of students. Many service industries such as banking and airlines have accepted the importance of information technology in the delivery of their services (Zhu et al., 2002). The ability for an organization to compete depends very much on how well they use the information technology. Similar rules apply in education. With the advancement in the field of information technology, students have various expectations regarding how information technology can be used to assist in higher education. Therefore, universities are faced with the challenge of keeping up with these changes while being constrained by other factors such as funding, staff resource, and resistance to change.

This expectation highlights the importance of using various avenues which the Internet provides (such as social networking sites) for disseminating information to students compared to more traditional communication channels. Other studies have confirmed that social networking sites are an important means for learning and knowledge seeking (Kabilan et al., 2010; Wodzicki et $a l ., 2012)$. It has become a place where youths do not only look for information, but also express their views. Therefore, it is important for universities to fully utilise this channel for dissemination of information and to assist in the teaching and learning process. Kabilan et al. (2010), in their study on the use of Facebook among USM students, concluded that Facebook helped in learning English, even though their motive of joining Facebook was to socialize. Similarly, it may be hypothesized that social networking sites could be used to assist in the learning process of students.

\section{Managing Student Expectations}

This study set out to examine student expectations towards a university recently participating in the APEX. The focus group discussion and responses to open-ended questions illustrated student expectations are not only related to the program per se, but also to more general aspects of the university experience. From the analysis, several conclusions can be made with regard to these expectations.

\footnotetext{
P. Karupiah

I. H. M. Hashim

N. Mohd-Zaharim
} 
Students' expectations are consistent with the view of ever-changing universities in Malaysia and all over the world. The changing nature of higher education institutions, including universities, makes it very important for us to look into student expectations. In this study, student expectations focused mainly on expectations related to their projected future, teaching, learning and assessment processes and information technology and communication. Some students were anxious regarding their projected future. Some felt that they were unprepared for work and had the expectation that the university should better prepare them. Students were concerned about the process of teaching and learning at the university. They expected that the teaching and learning process would be improved with the help of the latest technology. Students relied on the Internet not only for gathering of information for their work, but they also saw it as an important means of disseminating information. In addition to this, faceless communication was seen as something that reduced the barriers of communication between them and their instructors.

Traditionally, when universities were seen as the bastion of knowledge, most institutions adopted an 'inside-out' approach towards student expectations, i.e. assuming that they know what the best is for the students (similar to how parents feel about their children). With the current trend where universities are becoming more like business organisations and are expected to compete with other institutions in a market place, their success may depend on how well they adapt to customer expectations, i.e. they need to adopt a more outside-in approach. This is because successful service industries depend very much on how well they meet customer expectations (Sander et al., 2000).

Managing student expectations is important in a university, but at the same time it is important for the university to recognise that the nature of customers and consumption in the university is very different from other service industries. The university cannot deliver purely based on expectations of the students. Other than practical problems such as funding, space and other resources, a university plays an important role in imparting knowledge, values and ethics. It needs to train students according to the needs of each field. These roles are important for the functioning of society. Therefore, the university needs to identify realistic expectations of the students and work towards fulfilling those expectations. So, what do you do with the unrealistic expectations? We suggest that the unrealistic expectations should be identified and the university needs to educate and explain why these expectations are unrealistic and will not be addressed. This will help reduce the disappointment and frustration which students may feel when they are at the university. It will also reduce the mismatch between student expectations and university policy and programs.

Students enrolled in programmes which do not provide specific vocational training expected more training with skills with can be used in their future workplace. Whilst this is a good expectation and is something which can be improved at USM, there is a need for the university to ensure that students become more aware of the nature of their programmes. Orientation programmes at the university may need to address these issues to ensure that students are more ready to undergo life as undergraduates. Further, it is important to let them know what is expected of them during the course of their programmes. Students need to be made aware of the roles of a university, along with their own roles and responsibilities in higher education. This is

P. Karupiah
I. H. M. Hashim
N. Mohd-Zaharim


because the effectiveness of their learning process and the success of the university depend very much on their effort and participation.

Students need more support for their career choice because they see the main function of a university is to prepare them for work. Even though this view is becoming more dominant in recent years, it is not entirely coherent with the nature and role of universities. Besides professional training, universities are responsible for moral, civic and intellectual development (Grubb \& Lazerson, 2005). Further, in the world of work today and in many fields, the lessons from the classroom may be obsolete in five to ten years after students graduate. So, career success may depend mostly on how fast and well individuals learn according to the changing nature of their job, i.e. the process of lifelong learning may become important. A study among Dutch graduates showed that one-third of skills learnt will become obsolete in seven years. Even though popular beliefs suggest that more specialized fields suffer from this problem, this study showed that both specialized and generic fields face the problem of obsolescence (Allen \& van der Velden, 2002). Therefore, the bigger role of a university, other than to train skills related to the workplace, is to instil values and qualities in its students to ensure that they are able to adapt to the world of work. Only then will the students experience a more holistic and meaningful education. In addition, the mismatch between student expectation and university policy and programs can be addressed by creating awareness among students prior to their entry to a university. This can be done by having more comprehensive advice and guidance services in secondary schools. A better understanding regarding the programs in the university will enable students to choose programs which are suitable to their interests and personal goals. They therefore, would have more realistic expectations when enrolling in a program at university. This will further help to reduce the mismatch between student expectations and university policy and programs.

\section{References}

Abdullah, F. (2006) 'Measuring service quality in higher education: HEdPERF versus SERVPERF'. Marketing Intelligence \& Planning, 24 (1): 31-47. http://dx.doi.org/10.1108/02634500610641543

Allen, J and van der Velden, R. (2002) When do skills become obsolete, and when does it matter? In de Grip, A., van Loo, J. \& Mayhew, K. (eds.) The Economics of Skills Obsolescence (Research in Labor Economics, Volume 21). Oxford: Emerald Group Publishing Limited.

Bay, D. and Daniel, H. (2001) 'The student is not the customer - an alternative perspective'. Journal of Marketing for Higher Education, 11 (1): 1-19. http://dx.doi.org/10.1300/J050v11n01_01

Darlaston-Jones, D., Pike, L., Cohen, L., Young, A., Haunold, S. and Drew, N. (2003) 'Are they being served? Student expectations of higher education'. Issues in Educational Research, 13 (1): 31-52. 
Fernandez, J. L. (2010) 'An exploratory study of factors influencing the decision of students to study at Universiti Sains Malaysia'. Kajian Malaysia, 28 (2): 107-136.

Gikandi, J. W., Morrow, D. and Davis, N. E. (2011) 'Online formative assessment in higher education: A review of the literature'. Computers \& Education, 57 (4): 2333-51 http://dx.doi.org/10.1016/j.compedu.2011.06.004

Grubb, W. N. and Lazerson, M. (2005) 'Vocationalism in higher education: the triumph of the education Gospel'. The Journal of Higher Education, 76 (1): 1-25. http://dx.doi.org/10.1353/jhe.2005.0007

Jones, G. (2010) 'Managing student expectations: the impact of top-up tuition fees'. Perspectives: Policy and Practice in Higher Education, 14 (2): 44-48. http://dx.doi.org/10.1080/13603101003776135

Kabilan, M. K., Ahmad, N. and Abidin, M. J. Z. (2010) 'Facebook: an online environment for learning of English in institutions of higher learning'. The Internet and Higher Learning, 13 (4): 179-187. http://dx.doi.org/10.1016/j.iheduc.2010.07.003

Karupiah,P., Hashim, I. and Mohd-Zaharim, N. (2010) 'Accelerated Programme for Excellence (APEX): Expectations of Undergraduate Students'. Bulletin of Higher Education, 16: 5-6.

Kaye, T. S., Bickel, R. D. and Birtwistle, T. (2006) 'Criticizing the image of the student as consumer: examining legal trends and administrative responses in the US and UK'. Education and the Law, 18 (2-3): 85-129. http://dx.doi.org/10.1080/09539960600919779

Lee, H. G. (2014) 'Malaysia's funding system for higher education not sustainable'. ISEAS Perspective, 2: 1-11. Available from: http://www.iseas.edu.sg/documents/publication/ISEAS\%20Perspective\%202014_02\%20\%20Malaysia's\%20Funding\%20System\%20for\%20Higher\%20Education\%20not\%20Sustainabl e.pdf (accessed 16/6/14).

Lee, M. N. (2004) 'Global trends, national policies and institutional responses: restructuring higher education in Malaysia'. Educational Research for Policy and Practice, 3 (1): 31-46. http://dx.doi.org/10.1007/s10671-004-6034-y

Nik Husin, N. H., Yusoff, N. and Abd. Razak, R. R. (2012) Historical background and chronology of USM in the context of APEX University. In Ooi K. G. (ed) Excellence and Sustainability: USM and the APEX Journey. Volume 1: The Road ahead. Penang: Universiti Sains Malaysia.

Parasuraman, A., Zeithaml, V. A. and Berry, L. L. (1988) 'SERVQUAL: A multiple-item scale for measuring consumer perception of service quality'. Journal of Retailing, 64 (1): 12-40. 
Parasuraman, A. and Grewal, D. (2000) 'The impact of technology on the quality-value-loyalty chain: a research agenda'. Journal of the Academy of Marketing Science, 28 (1): 168-174. http://dx.doi.org/10.1177/0092070300281015

Pereda, M., Airey, D. and Bennet, M. (2007) 'Service quality in overseas education: the experience of overseas students'. Journal of Hospitality, Leisure, Sport and Tourism Education, 6 (2): 55-67. http://dx.doi.org/10.3794/johlste.62.160

Razak, D. A. and Mohamed, R. (2008) 'Transforming higher education for a sustainable tomorrow'. Penang: Universiti Sains Malaysia. Available from:

https://globalhighered.files.wordpress.com/2010/08/usmapex-universityintro.pdf (accessed 20/5/14).

Razak, D. A. (2009) 'USM APEX University status: transforming higher education for a sustainable tomorrow (editorial)'. Malaysian Journal of Medical Sciences, 16 (1): 1-6.

Sander, P., Stevenson, K., King, M. and Coates, D. (2000) 'University students' expectations of teaching'. Studies in Higher Education, 25 (3): 309-323.

http://dx.doi.org/10.1080/03075070050193433

Wan, C. D. (2007) 'Public and private higher education institutions in Malaysia: competing, complementary or crossbreeds as education providers'. Kajian Malaysia, 25 (1): 1-14.

Wan, C. D. (2012) 'The changing gender disparity in Malaysian higher education: where are the boys?' Bulletin of Higher Education Research, 20: 4-7. Available from:

http://www.ipptn.usm.my/index.php/publications/bulletin?download=43:no-20-bulletin-of-

higher-education (accessed 15/6/14).

Wodzicki, K., Schwämmlein, E., \& Moskaliuk, J. (2012) '"Actually, I wanted to learn": Studyrelated knowledge exchange on social networking sites'. The Internet and Higher Education, 15 (1): 9-14. http://dx.doi.org/10.1016/j.iheduc.2011.05.008

Urban, W. (2009) 'Service quality gaps and their role in service enterprises development'. Baltic Journal on Sustainability, 15 (4): 631-645.

Zhu, F. X., Wymer, W. and Chen, I. (2002) 'IT-based services and service quality in consumer banking’. International Journal of Service Industry Management, 13 (1): 69-90. http://dx.doi.org/10.1108/09564230210421164 


\section{Notes}

${ }^{1}$ Estimated from information from Lee (2014) and Wan (2012).

${ }^{2}$ The preliminary findings from the first two groups of focus group interview were published as Karupiah, Hashim \& Mohd-Zaharim (2010).

\section{Acknowledgement}

This study was supported by the Research University Grant, Universiti Sains Malaysia.

\section{About the authors}

Premalatha Karupiah is a Senior Lecturer in the School of Social Sciences at Universiti Sains Malaysia in Malaysia.

Email: prema@usm.my

Intan Hashimah Mohd Hashim is an Associate Professor in the School of Social Sciences, Universiti Sains Malaysia in Malysia.

Email: hashimah@usm.my

Norzarina Mohd-Zaharim is a Senior Lecturer in the School of Social Sciences at Universiti Sains Malaysia in Malaysia.

Email: norzarina@usm.my 